\title{
Pengaruh Model Pembelajaran Outdoor Study Berbantuan Video Conference terhadap Kemampuan Menulis Karya Ilmiah Mahasiswa
}

\author{
Wolfgang Asindo Seran ${ }^{1}$, Dwiyono Hari Utomo ${ }^{1}$, Budi Handoyo ${ }^{1}$ \\ ${ }^{1}$ Pendidikan Geografi-UniversitasNegeri Malang
}

\begin{tabular}{l}
\hline INFO ARTIKEL \\
\hline Riwayat Artikel: \\
Diterima: $10-07-2019$ \\
Disetujui: $10-02-2020$ \\
\hline
\end{tabular}

\section{Kata kunci:}

outdoor study, video conference; scientific work; outdoor study; video conference; karya ilmiah

\begin{abstract}
ABSTRAK
Abstract: This research is aimed at explaining the effect of outdoor study learning model assisted by video conference toward the learners' scientific writing competence. This research used quasi experiment with two groups, they are experiment class and control class. The subjects of this research were geography learners FIS university of Negeri Malang in the academic year 2019/2020 which consisted of two classes, experiment class contained 39 learners, meanwhile control class contained 37 learners. The technique that was used to determine the class was purposive sampling. The factorial design $2 \times 3$ was also used in this research. The data was analysed by using two way anova. The results show the significant value of hypothesis test by using two way anova as large as $0,035<0,05$ which meant there was an effect of outdoor study learning model assisted by video conference toward the learners' scientific writing competence.

Abstrak: Penelitian ini bertujuan untuk menjelaskan pengaruh model pembelajaran outdoor study berbantuan video conference terhadap kemampuan menulis karya ilmiah mahasiswa. Penelitian ini menggunakan eksperimen semu (quasi experiment) dengan dua kelompok yaitu kelas eksperimen dan kelas kontrol. Subjek penelitian mahasiswa geografi FIS Universitas Negeri Malang tahun ajaran 2019/2020 terdiri dari dua kelas, kelas eksperimen dengan jumlah 39 mahasiswa, sedangkan kelas kontrol dengan jumlah 37 mahasiswa total 76 mahasiswa. Teknik penentuan kelas menggunakan purposive sampling. Desain faktorial $2 \times 3$ yang digunakan dalam penelitian ini. Analisis data menggunkaan two way anova. Hasil penelitian menunjukkan nilai signifikan uji hipotesis two way anova sebesar $0,035<0,05$ yang berarti ada pengaruh model pembelajaran outdoor study berbantuan video conference terhadap kemampuan menulis karya ilmiah mahasiswa.
\end{abstract}

\author{
AlamatKorespondensi: \\ Wolfgang Asindo Seran \\ Pendidikan Geografi \\ Universitas Negeri Malang \\ Jalan Semarang 5 Malang \\ E-mail: Wolfgangasindo@gmail.com
}

Pembelajaran Geografi pada abad 21 ini menuntut mahasiswa agar dapat menyelesaikan masalah pada dunia yang nyata pada konteks materi tertentu yang seharusnya diimplementasikan di lapangan. Paradigma pembelajaran Geografi harus searah pada tuntutan paradigma baru dalam dunia pendidikan, seperti (1) materi pembelajaran yang berbasis konteks dunia nyata yang harus di pelajari mahasiswa, (2) berpusat pada mahasiswa (student centered), demokratis, dan fleksibel, (3) proyek kolaboratif untuk memecahkan masalah secara koperatif, (4) merancang desain dan meneliti secara mendalam, (5) kesediaan melakukan refleksi, (6) dosen atau guru Geografi diberikan peran sebagai fasilitator atau perantara, dan konsultan, (7) menggunakan komputer sebagai alat bantu pembelajaran dan menggunakan berbagai media dalam berkomunikasi, dan (8) penelitian kinerja dan penelitian produk lebih diprioritaskan (Handoyo, 2012). Sejalan dengan pendapat Susetyo, dkk (2017) berkaitan dengan era informasi, teknologi, dan komunikasi merupakan pembelajaran saat ini. Implikasi dalam hal ini manusia mempunyai peran sebagai pelaku utama dalam berbagai proses, dan aktivitas kehidupan manusia banyak mengalami perubahan secara fundamental pada Abad 21. Agenda global dan kemajuan teknologi informasi telah menghubungkan manusia menjadi lebih mudah saling berinteraksi dan berkomunikasi kapan saja, dimanapun mereka berada. Hal ini juga dosen atau guru harus memiliki strategi yang cocok dalam pemilihan model maupun metode yang akan diajarkan. Menurut Sudarman et al, (2018) guru kurang inovatif dalam pembelajaran disebabkan kurangnya pemilihan strategi yang tepat. 
Model outdoor study merupakan pembelajaran untuk berorientasi pada aktivitas mahasiswa yang di lakukan di luar lingkungan kelas. Tindakan atau aktivitas langsung di lapangan merupakan pembelajaran yang diperoleh melalui outdoor study (Szczepanski et al, 2006; Sumarmi, 2012; Vera, 2012; Sofnidar, dkk 2017). Dosen diharapkan dapat berinovasi untuk mengarahkan mahasiswa meningkatkan kemampuan berpikir secara kreatif, inovatif, dan secara aktif terhadap suatu permasalahan Geografi yang berada dalam kehidupan mahasiswa. Sejalan dengan pendapat Nursa'ban (2013) Dosen seyogyanya dapat berinovasi dalam pembelajaran dengan segala keterbatasan waktu dan fenomena yang ada disekitar sekolah sebagai bahan kajian pembelajaran.

Pembelajaran model outdoor study dapat membuat seseorang untuk aktif, inovatif, kreatif dalam proses pembelajaran yang lebih bermaknadan kontekstual dengan mendapatkan sumber belajar secara langsung. Pola pembelajaran study lapangan sesungguhnya melalui pengamatan langsung kepada objek dengan pembelajaran yang dapat meningkatkan kreativitas dan aktivitas bagi siswa secara kontekstual (Sumarmi, 2012; Robertson, 2014; Fatchanet al, 2016; Maulidiyahwarti et al, 2016). Dapat disimpulkan bahwa pembelajaran yang dilakukan di luar kelas (outdoor study) dapat memanfaatkan kondisi lingkungan sekitar mahasiswa atau di luar kampus sebagai pembelajaran yang tersusun dan terencana, dimana pembelajarannya dapat mengaktifkan kreativitas, kekritisan mahasiswa secara holistik.

Model pembelajaran outdoor study memiliki delapan langkah pembelajaran yang diadopsi dari (Fatchan et al, 2016; Purwanto et al, 2016) yang dikaitkan dengan aktivitas di lapangan sesuai materi perkuliahan, yakni (1) mengamati, kegiatan mahasiswa mengidentifikasi melalui indera penglihatan (menyimak, membaca), pendengar, peraba dan pengecap pada saat mengamati suatu objek yang ada di lapangan, (2) mengklasifikasi, kegiatan mahasiswa mengklasifikasi parameter, objek/subjek khususnya pada bidang pendidikan urbanisasi jenjang SD, SMP, dan SMA yang ada di Kota Malang, (3) mengkomunikasikan, kegiatan mahasiswa dapat berkomunikasi dengan teman sekelompok tentang parameter, objek terkait dengan permasalahan urbanisasi, (4) mengukur, kegiatan mahasiswa terhadap berbagai temuan dari objek di lapangan, (5) memprediksi, yaitu kegiatan mahasiswa memperhitungkan atau berasumsi mengenai apa yang harus dilakukan untuk mengatasi permasalahan urbanisasi, (6) menyimpulkan, kegiatan mahasiswa mengkaji ulang semua hasil temuan di lapangan dari kegiatan pertama sampai sampai memprediksi sesuai tujuan outdoor study, (7) menulis hasil laporan, kegiatan mahasiswa setelah pelajaran di luar kelas apa yang mereka (mahasiswa) peroleh di lapangan dibuat dalam bentuk karya ilmiah (artikel), (8) mempresentasikan, hasil dari kegiatan outdoor mahasiswa kemudian membuat karya ilmiah dalam bentuk artikel jurnal ilmiah dan dipresentasikan di kelas. Pada penelitian ini, pembelajaran outdoor study cocok digunakan dalam pembelajaran Geografi dimodifikasi dengan menggunakan video conference sehingga proses pembelajaran yang terjadi semakin membangkitkan semangat kerja mahasiswa dalam menyelesaikan tugas belajarnya secara aktif dan kreatif. Sejalan dengan pendapat Ardley (2009) mengatakan bahwa pembelajaran dengan konferensi video dapat membangkitkan rasa semangat anak dalam proses pembelajaran.

Video conference atau konferensi video merupakan telekomunikasi interaktif yang memungkinkan komunikasi antara dua orang atau lebih di lokasi yang berbeda sehingga dapat berinteraksi melalui pengiriman dua arah video dan audio bersamaan secara online. Konferensi video melibatkan dosen dan mahasiswa berinteraksi secara bersamaan, tetapi tidak harus berada di lokasi yang sama (Azwar \& Susantok, 2013). Selama masih dalam pembelajaran para dosen dan mahasiswa dapat berkomunikasi melalui video ataupun audio untuk interaktif dua arah, dosen dan mahasiswa saling dapat melihat (bertatapan muka) dan mendengar satu sama lain menggunakan laptop ataupun dengan menggunakan smartphone android (Hogan \& Rinn, 1999; Koenig, 2010). Keuntungan dari video conference dapat memonitori pembelajaran secara langsung di lapangan tanpa memonitoring dari satu lokasi ke lokasi yang lain. Oleh karena itu, dalam proses pembelajarannya juga memerlukan suatu karya tulis ilmiah agar dapat bersaing di era digital 4.0.

Karya ilmiah (scientific paper) merupakan laporan atau tulisan pengkajian suatu masalah oleh seseorang atau tim dengan memenuhi kaidah dan etika keilmuan yang dikukuhkan dan ditaati oleh masyarakat keilmuan dari hasil penelitiannya. Mengikuti pedoman yang telah ditetapkan dan yang telah disepakati yang meliputi bidang ilmu pengetahuan, teknologi, dan seni adalah penulisan karya ilmiah yang dikerjakan sesuai dengan tata cara ilmiah (Saukuh, dkk 2010; Razi, 2018). Dapat disimpulkan bahwa observasi pengamatan, dan penyelidikan dari suatu penelitian seseorang maupun sebuah tim merupakan karya tulis ilmiah melalui penelitian lapangan yang didasarkan pada pemikiran ilmiah yang logis dan empiris merupakan karya ilmiah. Karya ilmiah dalam pelaporan hasil dari pembelajaran di luar kelas pada objek maupun subjek yang di teliti oleh mahasiswa nantinya berupa artikel hasil penelitian. Mahasiswa melatih dengan menulis dan menuangkan baik gagasan maupun ide dalam karya tulis. Tulisan ilmiah seseorang dapat menuangkan pikiran, ide, dan novelty (Rahmiati, 2013; Suyono, dkk 2016; Razi, 2018). Karya tulis yang dibuat dengan kolaborasi kelompok dari hasil persepsi dan pemikiran setiap anggota kelompok.

Artikel jurnal ilmiah sebagai suatu karya ilmiah ditulis untuk memenuhi tugas perkuliahan atau ditulis untuk disajikan dalam suatu forum ilmiah PPKI UM (2018). Bukan semata-mata sebagai usaha untuk melatih diri, melainkan kegiatan semacam ini telah menjadi pupuk yang mampu menyamai bibit-bibit penulis produktif yang diharapkan ke depan menjadi pendonor bagi jantung perguruan tinggi. Penulisan karya ilmiah Geografi mahasiswa dapat dijadikan motivasi kepada mereka untuk mengikuti LKTI (Lomba Karya Tulis Ilmiah), dan PKM (Program Kreativitas Mahasiswa). Menurut data (2018) daftar PKM lima bidang yang sudah disetor ke KASUBBAG MPIKA UM hasil PKM hanya 25 mahasiswa Geografi yang mengikuti PKM yang sudah dikirim ke pusat. Selanjutnya, bagi yang terpilih dapat bersaing di tingkat PIMNAS (Pekan Ilmiah Mahasiswa Nasional). Hasil yang dicapai oleh mahasiswa kelak dapat diunggah, dijadikan rujukan, dan dibaca semua orang, semuanya itu kembali kepada visi dan misi Universitas Negeri Malang yaitu sebagai kampus rujukan. 


\section{METODE}

Penelitian ini menggunakan eksperimen semu (quasi experiment) dengan dua kelompok, yaitu kelas eksperimen dan kelas kontrol. Kelas eksperimen mendapat perlakuan menggunakan model pembelajaran outdoor study berbantuan video conference, sedangkan kelas kontrol dengan menggunakan model pembelajaran konvensional (ceramah, diskusi, dan tanya jawab). Subjek penelitian ini mahasiswa Fakultas Ilmu Sosial Universitas Negeri Malang semester II Pendidikan Geografi tahun ajaran 2019/2020 yang terdiri dari dua kelas yang berjumlah 39 dan 37 mahasiswa keseluruhan total 76 mahasiswa yang heterogen. Kelas K dipilih sebagai kelas eksperimen dan kelas L sebagai kelas kontrol yang diperoleh dari nilai tes awal dan hasil produk awal kedua kelas dalam kemampuan menulis karya ilmiah.

Instrumen yang digunakan dalam penelitian ini adalah pedoman penulisan dan penilain karya ilmiah diadopsi dari Clabough \& Clabough (2016). Untuk pengategorian karya tulis ilmiah dimodifikasi dari rubrik penilaian Ristek Dikti (2017). Instrumen penelitian selain terkait dengan karya tulis, terdapat juga yang berhubungan dengan outdoor study berbantuan video conference. Instrumen yang dimaksud adalah langkah-langkah model pembelajaran outdoor study berbantuan video conference, SAP (Satuan Acara Perkuliahan), RPS (Rancangan Perkuliahan Semester), Wacana, dan LKM (Lembar Kerja Mahasiswa). Instrumen-instrumen tersebut perlu divalidasi oleh dosen ahli supaya layak digunakan untuk penelitian. Validator untuk menilai instrumen ini adalah dosen yang menguasai pembelajaran sekaligus materi Geografi.

Analisis data penelitian ini menggunakan uji two way anova menggunakan SPSS 16.0 for windows. Sebelum dilakukan analisis data, (uji hipotesis) terlebih dahulu dilakukan uji prasyarat analisis. Uji prasyarat analisis, meliputi uji normalitas dan homogenitas. Uji hipotesis menggunakan two way anova dua jalur dengan bantuan SPSS. 16.0 for windows pada taraf signifikan 0,05. Analisis two way anova yang diukur adalah gain score setiap indikator dalam membuat artikel, meliputi abstrak, judul, pendahuluan, metode, hasil, pembahasan, simpulan, dan referensi baik kelas eksperimen maupun kelas kontrol.

\section{HASIL}

Kelas yang dijadikan sebagai kelas eksperimen yaitu offering $\mathrm{K}$ dan offering L sebagai kelas kontrol. Hasil penelitian ini terdapat perbedaan rata-rata skor test awal antara kelas eksperimen dan kelas kontrol. Rata-rata skor kemampuan menulis karya ilmiah soal test pada kelas eksperimen memperoleh skor sebanyak 52,41, sedangkan pada kelas kontrol memperoleh skor 51,83. Kedua hasil skor yang diperoleh dari tes awal termasuk dalam kategori sedang.

Setelah diberi perlakuan, terdapat perbedaan hasil skor rata-rata skor test akhir kelas eksperimen dan kelas kontrol. Pada kelas eksperimen ini termasuk kategori sangat baik dengan nilai 87,66 dan kelas kontrol juga dikategorikan sangat baik dengan nilai 87,00. Alasan mengapa selisih nilai kedua kelas eksperimen maupun kelas kontrol dapat dikatakan nilainya samasama hampir setara karena yang Pertama, penyampaian materi oleh peneliti sebelum diujicobakan, dan juga setelah itu peneliti memberikan penjelasan ulang untuk diujicobakan diakhir pertemuan. Kedua, nilai UTS semester I kelas eksperimen dan kelas kontrol sama-sama baik. Ketiga, soal essay yang sudah divalidasi diberikan oleh peneliti tidak terlalu menyulitkan bagi mahasiswa semester II sehingga mahasiswa kelas eksperimen dan kelas kontrol dapat berpikir sesuai ide dan gagasan mereka masing-masing. Keempat, asumsi peneliti mengenai IQ setiap mahasiswa kelas eksperimen maupun kelas kontrol berbeda-beda dalam menyelesaikan suatu permasalahan. Adapun perbandingan nilai rata-rata test awal dan test akhir (kognitif) kelas eksperimen dan kelas kontrol dapat dilihat pada gambar 1.

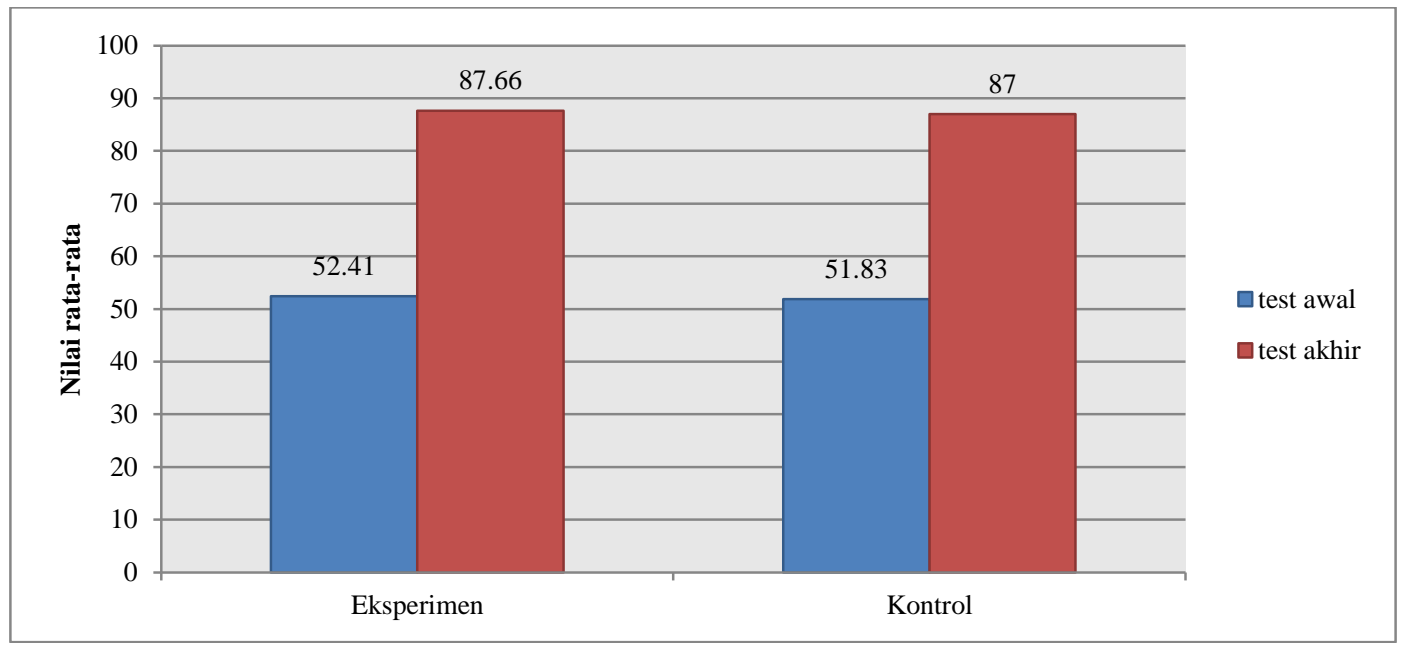

Gambar 1. Perbandingan Nilai Rata-Rata Test Awal dan Test Akhir Kelas Eksperimen dan Kelas Kontrol 
Nilai Produk Awal Kelas Eksperimen dan Kelas Kontrol

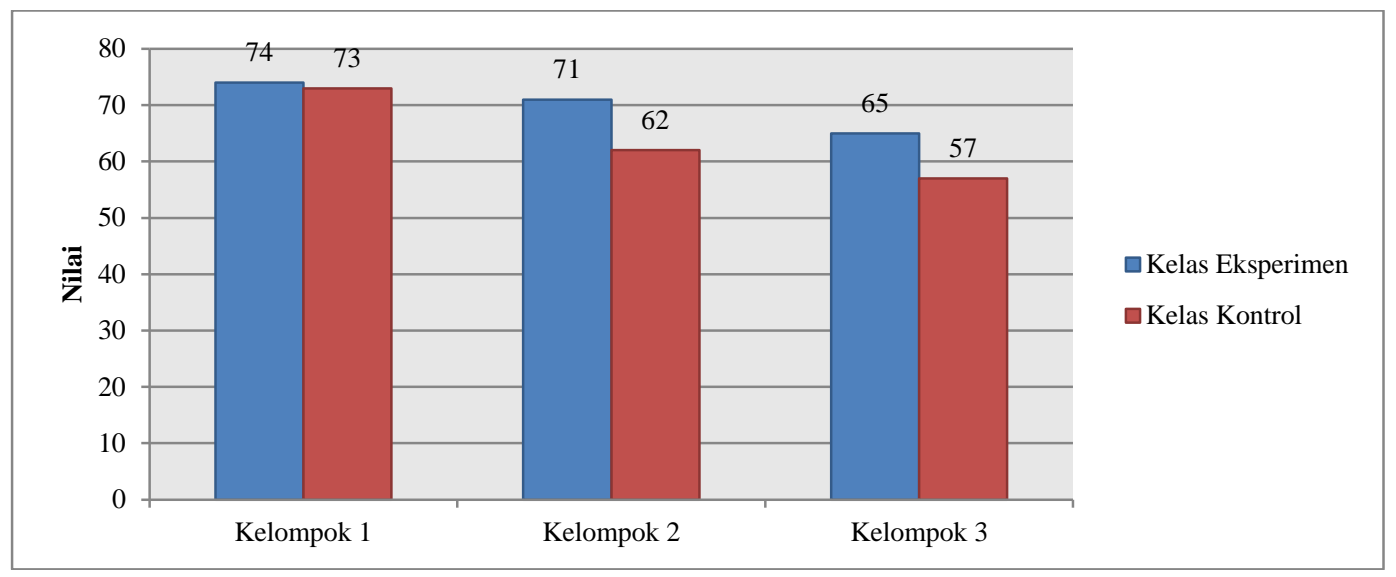

Gambar 2. Nilai Produk Awal Kelas Eksperimen dan Kelas Kontrol

Gambar 2 nilai produk awal dalam penelitian ini diperoleh dari wacana yang berkaitan dengan materi geografi desa kota untuk melihat keterampilan (proses) awal setiap kelompok baik kelompok I, II, dan III dalam menulis karya ilmiah. Berdasarkan data pada kelompok I diperoleh nilai produk awal kelas eksperimen tertinggi dengan skor 74, sedangkan kelas kontrol kelompok I dengan skor 73. Pada kelompok II kelas esksperimen memperoleh nilai 71, sedangkan pada kelompok II kelas kontrol memperoleh nilai 62. Pada kelompok III kelas eksperimen memperoleh nilai 70,00 sedangkan kelas kontrol 64,00. Selisih dari kedua kelas tersebut sebesar 6,00. Kelas eksperimen lebih unggul dalam memperoleh nilai rata-rata dari kelas kontrol.

Nilai Produk Akhir Kelas Eksperimen dan Kelas Kontrol

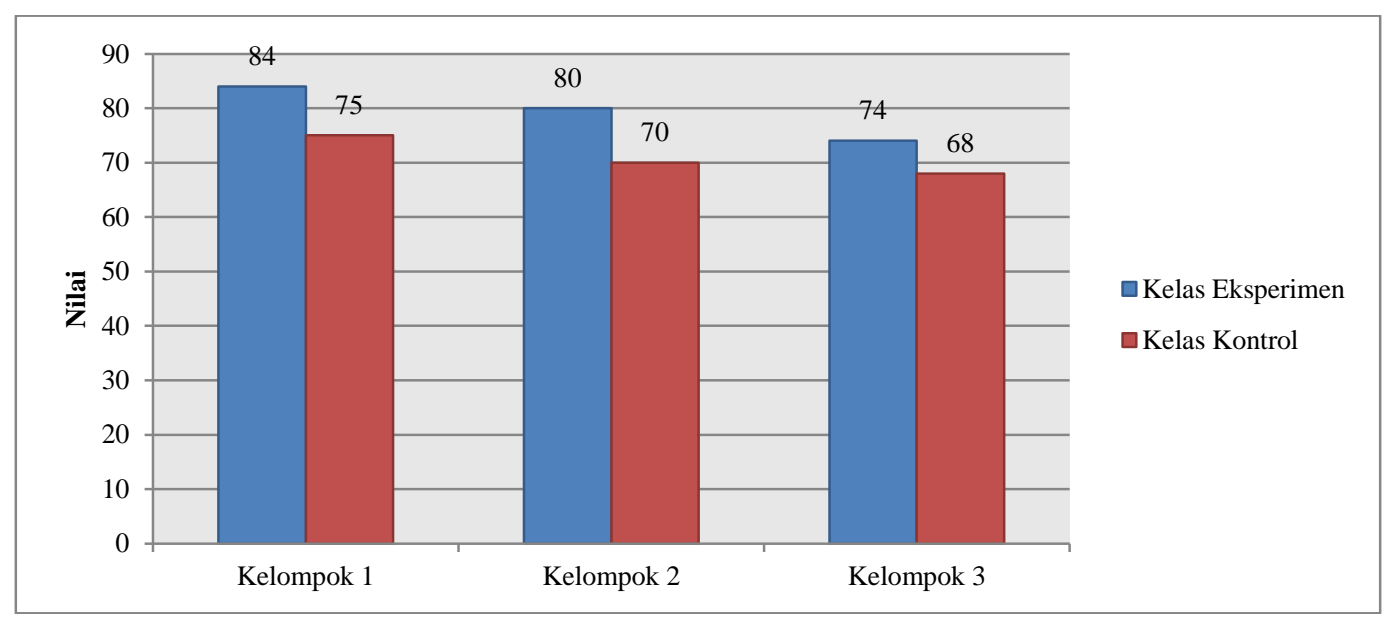

Gambar 3. Nilai Produk Akhir Kelas Eksperimen dan Kelas Kontrol

Gambar 3 nilai produk akhir diperoleh setelah kelas kontrol dan kelas eksperimen mendapatkan pembelajaran yang berbeda, tetapi materi yang sama. Kelas eksperimen mendapatkan perlakuan dengan meneliti langsung di lapangan menggunakan model pembelajaran outdoor study berbantuan video conference, sedangkan kelas kontrol menggunakan pembelajaran konvensional. Pada nilai akhir produk ini berbeda dengan nilai produk awal, bedanya yaitu kelompok eksperimen maupun kelompok kontrol membuat artikel secara keseluruhan dari abstrak, judul, pendahuluan, metode, hasil, pembahasan, kesimpulan, dan referensi secara lengkap. Berbeda halnya dengan produk awal yaitu bagian judul, rumusan masalah, tujuan, metode, hasil dan pembahasan, kesimpulan, dan daftar rujukan. Pada produk awal hanya ingin mengetahui (keterampilan proses) setiap kelompok mahasiswa dan juga sebagai penentuan kelas eksperimen maupun kelas kontrol. Dengan demikian, pada bagian produk akhir, nilai rata-rata (gain score) setiap kelompok mahasiswa nantinya akan dianalisis menggunakan SPSS 16.0 for windows dan two way anova. 
Data nilai produk akhir antara kedua kelas baik kelas eksperimen maupun kelas kontrol memiliki nilai berbeda. Perbedaan tersebut pada nilai tertinggi dan nilai terendah. Kelas eksperimen kelompok I memperoleh nilai sebesar 84, sedangkan kelas kontrol kelompok I memperoleh nilai 75. Kelas eksperimen kelompok II memperoleh nilai 80, sedangkan kelas kontrol kelompok II memperoleh nilai 70. Kelas eksperimen kelompok III memperoleh nilai 74, sedangkan kelas kontrol kelompok III memperoleh nilai 68. Data lengkapnya dapat dilihat pada tabel 1.

Tabel 1. Perbandingan Gain Score Karya Tulis Ilmiah Kelas Eksperimen dan Kelas Kontrol

\begin{tabular}{llcccccc}
\hline No & Bagian & \multicolumn{3}{c}{ Kelompok Eksperimen } & \multicolumn{3}{c}{ Kelompok Kontrol } \\
\hline & & Kelompok I & Kelompok II & Kelompok III & Kelompok I & Kelompok II & Kelompok III \\
\hline 1 & Abstrak & 9,09 & 8,16 & 7,22 & 9,09 & 8,16 & 7,22 \\
2 & Judul & 8,08 & 7,14 & 6,19 & 5,05 & 6,12 & 5,15 \\
3 & Pendahuluan & 7,07 & 6,12 & 5,15 & 7,07 & 5,10 & 5,15 \\
4 & Metode & 6,06 & 4,08 & 4,12 & 6,06 & 6,12 & 3,09 \\
5 & Hasil & 16,16 & 12,24 & 11,34 & 13,13 & 10,2 & 9,28 \\
6 & Pembahasan & 7,07 & 6,12 & 3,09 & 9,09 & 5,10 & 4,12 \\
7 & Simpulan & 9,09 & 8,16 & 7,22 & 9,09 & 8,16 & 7,22 \\
8 & Referensi & 14,14 & 13,27 & 7,22 & 9,09 & 6,12 & 3,09 \\
\hline \multicolumn{2}{r}{ Jumlah } & $\mathbf{7 6 , 7 6}$ & $\mathbf{6 5 , 2 9}$ & $\mathbf{5 1 , 5 5}$ & $\mathbf{6 7 , 6 7}$ & $\mathbf{5 5 , 0 8}$ & $\mathbf{4 4 , 3 2}$ \\
\hline
\end{tabular}

Tabel 1 menunjukkan bahwa peningkatan kelas eksperimen kelompok I terdapat pada bagian judul, hasil, dan referensi yaitu nilai gain score 8,08, 16,16, dan 14,14, dengan total jumlah sebesar 76,76 yang dikategorikan baik, sedangkan kelas kontrol terdapat peningkatan pada bagian pembahasan dengan nilai gain score 9,09. Selisih dengan kelas eksperimen dari bagian pembahasan 2,02 dengan total jumlah kelas kontrol sebesar 67,67 yang dikategorikan baik. Pada kelompok II kelas eksperimen terdapat peningkatan pada bagian judul, pendahuluan, hasil, pembahasan, dan referensi dengan nilai gain score sebesar 7,14, 6,12, 12,24, 16,12, 13,27 dengan total jumlah sebesar 65,29 yang dikategorikan baik. Sedangkan pada kelas kontrol terdapat peningkatan pada bagian metode dengan nilai gain score sebesar 6,12. Selisih pada bagian metode dari kedua kelas tersebut sebesar 0,06 dengan total jumlah sebesar 55,08 yang dikategorikan sedang. Pada kelompok III untuk kelas eksperimen terdapat peningkatan pada bagian judul, metode, hasil, dan referensi dengan nilai gain score sebesar 6,19, 4,12, 11,34, dan 7,22 dengan total jumlah sebesar 51,55 yang dikategorikan sedang. Untuk kelas kontrol terdapat peningkatan pada bagian pembahasan dengan nilai gain score sebesar 4,12. Selisih pada bagian pembahasan dari kedua kelas tersebut sebesar 1,03 dengan total jumlah sebesar 44, 32 yang dikategorikan kurang. Hasil perbandingan gain score kemampuan menulis karya tulis ilmiah setiap bagian yang dianalisis dengan program SPSS 16.0 for windows. Lebih lengkapnya dapat dilihat setiap indikator kemampuan menulis karya ilmiah pada gambar 4.

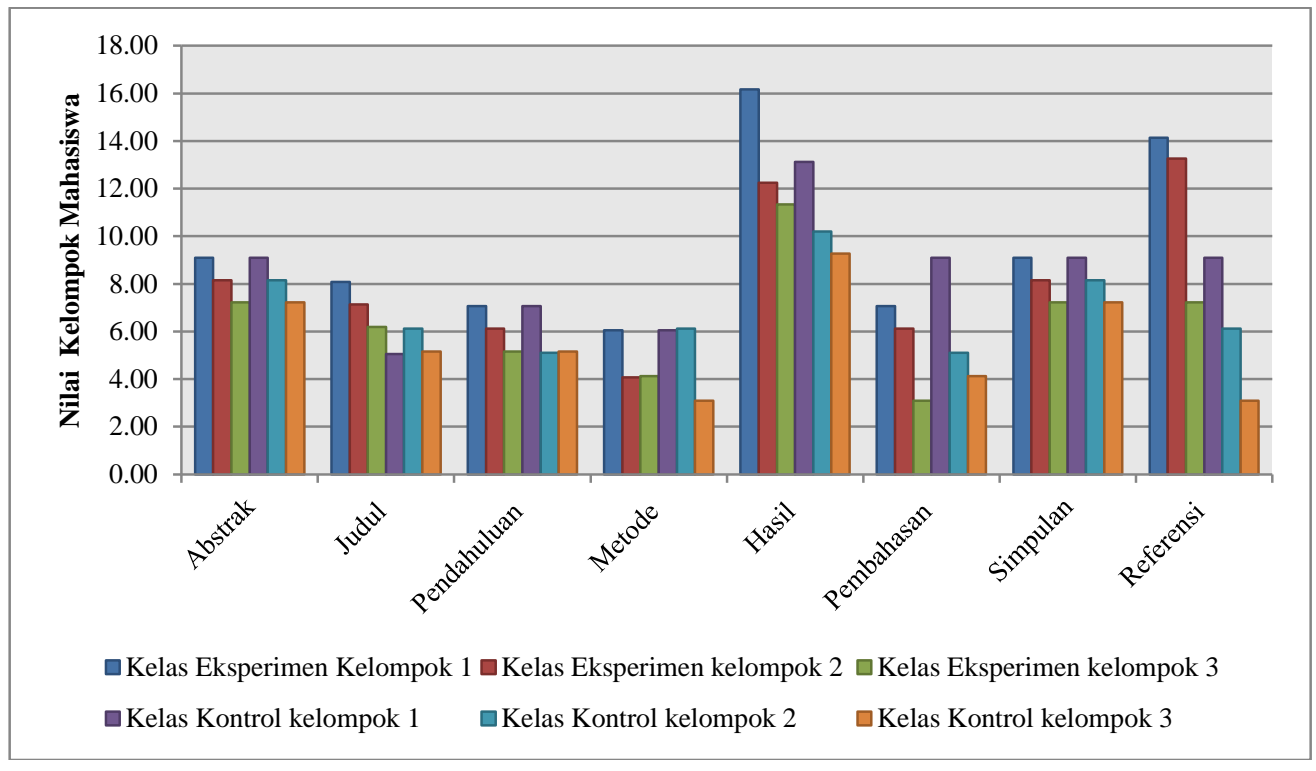

Gambar 4. Kemampuan Menulis Karya Ilmiah Setiap Indikator Kelas Eksperimen dan Kelas Kontrol 
Gambar 4 menunjukkan bahwa kelas eksperimen yang menggunakan model pembelajaran outdoor study berbantuan video conference lebih unggul dari kelas kontrol yang menggunakan pembelajaran konvensional (ceramah, diskusi, tanya jawab). Hal ini dibuktikan dengan hasil dari produk akhir yang dilakukan oleh kedua kelas. Pertama, kelas eksperimen unggul dari kelas kontrol dalam kemampuan menulis karya ilmiah terdapat pada bagian Judul, hasil, dan referensi. Pada bagian abstrak kelas eksperimen dalam memperoleh nilai dan kelas kontrol memperoleh nilai yang sama pada ketiga kelompok yakni sebesar 9.09, 8.16, dan 7,22. Pada bagian pendahuluan kelas eksperimen dan kelas kontrol untuk kelompok I dan kelompok III samasama memperoleh nilai sebesar 7,07 dan 5,5, sedangkan untuk kelas eksperimen kelompok II memperoleh nilai sebesar 6,12 lebih unggul dari kelas kontrol kelompok II dengan memperoleh nilai sebesar 5,10. Pada bagian metode, kelas eksperimen dan kelas kontrol kelompok I memperoleh nilai yang sama yaitu sebesar 6,06 untuk kelas eksperimen kelompok II memperoleh nilai sebesar 4,08 lebih rendah dari kelas kontrol yang memperoleh nilai sebesar 6,12, sedangkan untuk kelompok III kelas eksperimen memperoleh nilai sebesar 4,12 yang lebih unggul dari kelas kelompok kontrol yaitu sebesar 3,09. Pada bagian pembahasan kelas eksperimen kelompok 1 memperoleh nilai sebesar 7,07 yang agak rendah dari kelas kontrol kelompok I yang memperoleh nilai sebesar 9,09 untuk kelompok II kelas eksperimen memperoleh nilai sebesar 6,12 lebih unggul dari kelas kontrol yang memperoleh nilai sebesar 5,1. Sementara itu, kelas eksperimen kelompok III memperoleh nilai sebesar 3,09 sedikit rendah dari kelas kontrol kelompok III yang memperoleh nilai sebesar 4,12. Pada bagian simpulan kelas eksperimen dan kelas kontrol memperoleh nilai yang sama yaitu sebesar 9,09, 8,16, dan 7,22.

Kedua, alasan mengapa kelas eksperimen menggunakan model pembelajaran outdoor study berbantuan video conference terjadi peningkatan pada bagian judul, hasil, dan referensi karena pada kelompok mahasiswa kelas eksperimen dapat merekam apa yang dilihat, diamati, dan dirasakan kemudian dituangkan dalam karya ilmiah. Menurut Gagne dalam Rehalat (2014) mengatakan bahwa tentang pomrosesan informasi yaitu (1) panca indera yang diterima kemudian disalurkan pada syaraf dan diproses sebagai informasi, (2) informasi yang didapat dipilih secara seksama secara selektif dan disimpan dalam memori jangka pendek dan jangka panjang dan, (3) informasi yang sudah didapatkan semuanya kemudian diungkap kembali. Sedangkan, untuk kelas kontrol terjadi peningkatan pada bagian metode dan pembahasan saja namun tidak terlalu besar peningkatannya dengan kelas eksperimen. Sejalan dengan pendapat Slavin (2000) pemrosesan informasi berkaitan dengan penyimpanan dan pemangilan kembali pengetahuan yang didapatkan dari otak. Alasan peningkatan kelas kontrol pada bagian metode disebabkan yaitu kelompok kontrol mecari data sekunder yang sesuai dengan topik/permasalahan yang diambil dan untuk pembahasan kelompok kelas kontrol menyajikan pembahasan yang sesuai dengan kriteria yang ditentukan.

Ketiga, alasan yang ketiga yaitu kelompok mahasiswa kelas eksperimen dalam kemampuan menulis karya ilmiah bagian judul telah memenuhi syarat pada kriteria yang ditentukan yakni halaman judul tidak lebih dari 5-14 kata dan judul menggambarkan isi penelitian. Pada bagian hasil kelas eksperimen telah memenuhi syarat pada kriteria yang ditentukan yakni, (1) tidak mengandung informasi yang seharusnya berada dibagian pendahuluan, metode, atau pembahasan, (2) mengandung semua informasi yang diperlukan untuk mendukung hasil yang diperoleh di lapangan, (3) setiap tabel dan gambar diberi nomor dan judul deskriptif sehingga dapat dipahami, (4) semua tabel dan gambar dirujuk pada apa yang ditulis. Pada bagian referensi kelas eksperimen telah memenuhi syarat pada kriteria yang ditentukan yakni referensi yang ditulis sesuai dengan referensi yang dirujuk dalam naskah, referensi menunjang isi naskah dan dipilih sebagian besar dari jurnal, dan penulisan konsisten.

Data pada gambar 4 menunjukkan terdapat pengaruh signifikan antara model pembelajaran outdoor study berbantuan video conference terhadap kemampuan menulis karya ilmiah. Hal ini dibuktikan dengan uji two way anova yang terdapat pengaruh signifikan sebesar 0,035 lebih kecil dari 0,05 sehingga model pembelajaran outdoor study berbantuan video conference berpengaruh signifikan terhadap kemampuan menulis karyai ilmiah mahasiswa.

\section{PEMBAHASAN}

Hasil uji hipotesis two way anova menunjukkan bahwa model pembelajaran outdoor study berbantuan video conference berpengaruh signifikan terhadap kemampuan menulis karya ilmiah mahasiswa. Pengaruh signifikan ditunjukan dengan nilai signifikan sebesar 0,035 yang lebih kecil dari 0,05. Perolehan nilai rata-rata gain score setiap indikator pada kelas eksperimen lebih unggul dari kelas kontrol. Perbandingan rata-rata gain score disebabkan adanya perlakuan yang berbeda antara kedua kelas. Kelas eksperimen menggunakan model pembelajaran outdoor study berbantuan video conference sedangkan kelas kontrol menggunakan pembelajaran konvensional (ceramah, diskusi, tanya jawab). Hasil analisis ini membuktikan bahwa gain score yang diperoleh kelas kelompok eksperimen unggul dari kelas kelompok kontrol. Sehingga, disimpulkan bahwa pembelajaran menggunakan model outdoor study berbantuan video conference pada materi perkuliahan geografi desa kota dengan indikator memahami dan menganalisis permasalahan urbanisasi khususnya pada bidang pendidikan di Kota Malang berpengaruh terhadap kemampuan menulis karya ilmiah mahasiswa.

Temuan penelitian ini menunjukkan bahwa model pembelajaran outdoor study berbantuan video conference berpengaruh positif terhadap kemampuan menulis karya ilmiah. Artinya, kemampuan mahasiswa dalam menulis karya ilmiah dengan menggunakan model pembelajaran outdoor study berbantuan video conference lebih meningkat dibandingkan dengan pembelajaran konvensional (ceramah, diskusi, tanya jawab). Alasan mengapa kelas eksperimen yang menggunakan model pembelajaran outdoor study berbantuan video conference terjadi peningkatan pada bagian judul, hasil dan referensi karena pada kelompok mahasiswa kelas eksperimen dapat merekam apa yang dilihat, diamati, dan dirasakan kemudian dituangkan dalam karya ilmiah. Menurut Gagne dalam Rehalat (2014) pomrosesan informasi yaitu (1) panca indera yang diterima kemudian 
disalurkan pada syaraf dan diproses sebagai informasi, (2) informasi yang didapat dipilih secara seksama secara selektif dan disimpan dalam memori jangka pendek dan jangka panjang, dan (3) informasi yang sudah didapatkan semuanya kemudian diungkap kembali untuk membuat karya ilmiah. Untuk kelas kontrol terjadi peningkatan pada bagian metode dan pembahasan saja, namun tidak terlalu besar peningkatannya dengan kelas eksperimen. Sejalan dengan pendapat Slavin (2000) mengatakan bahwa pemrosesan informasi berkaitan dengan penyimpanan dan pemanggilan kembali pengetahuan yang didapatkan dari otak.

Model pembelajaran outdoor study berbantuan video conference memberikan pengaruh kemampuan menulis karya ilmiah mahasiswa. Peningkatan kemampuan menulis karya ilmiah mahasiswa merupakan konsekuensi positif dari pelaksanaan setiap tahapan/sintaks pembelajaran menggunakan model outdoor study berbantuan video conference mulai dari tahapan (1) mengamati, (2) mengklasifikasi, (3) mengomunikasikan, (4) mengukur, (5) memprediksi, (6) menyimpulkan, (7) membuat laporan, dan, (8) mempresentasikan. Rangkaian tahapan pembelajaran ini memberikan pengaruh positif bagi peningkatan kemampuan menulis karya ilmiah mahasiswa yang sesuai dengan indikator kemampuan menulis karya ilmiah (artikel hasil penelitian), meliputi (1) abstrak, (2) judul, (3) pendahuluan, (4) metode, (5) hasil, (6) pembahasan, (7) simpulan, dan (8) referensi. Proses menunjukkan aktivitas mahasiswa dalam memahami, mempraktikkan, dan mempresentasikan bagian penulisan karya ilmiah. Keberhasilan penggunaan model pembelajaran outdoor study berbantuan video conference dapat dilihat dari segi proses dan hasil dari setiap kelompok mahasiswa.

Kemampuan menulis karya ilmiah dapat berpengaruh dikarenakan mahasiswa melibatkan otak secara langsung mencari dan menemukan informasi yang diperoleh di lapangan. Sejalan dengan pendapat Utomo (2016) mengatakan bahwa belajar di pendidikan tinggi mahasiswa dapat mencari dan menemukan informasi yang melibatkan otak secara aktif melalui kegiatan belajar. Pada setiap sintak/tahapan pembelajaran outdoor study berbantuan video conference yang dijalankan melatih dan membelajarkan mahasiswa pada peningkatan kemampuan menulis karya ilmiah bermuatan data dan fakta yang mahasiswa jumpai di lapangan. Fakta dan data yang dijumpai mahasiswa di lapangan dituangkan dalam bagian hasil dan pembahasan. Fakta tentang urbanisasi dijadikan sebagai latar belakang dilengkapi dengan foto lokasi di kedua titik antara Kabupaten Malang dan Kota Malang. Fakta tersebut juga memudahkan mahasiswa merumuskan masalah dan tujuan penelitian.

Tahapan pembelajaran yang memberikan pengaruh positif terhadap peningkatan kemampuan menulis karya ilmiah mahasiswa (artikel hasil penelitian) antara lain: pertama, mengamati objek dan subjek. Pada tahapan ini mahasiswa dalam kelompok secara langsung mengenali permasalahan kota yang berkaitan dengan permasalahan urbanisasi khususnya pada bidang pendidikan jenjang SD, SMP, dan SMA pengamatan ini dibagi menjadi dua titik lokasi pengamatan, titik pertama di sebelah barat Kampus UMM (Tugu selamat datang Kabupaten Malang dan Kota Malang)titik kedua di sebelah selatan pasar Gadang (Tugu selamat datang Kabupaten Malang dan Kota Malang) disini mahasiswa dapat mengetahui secara langsung karakteristik, lokasi, dan argumentasi mengapa sampai permasalahan urbanisasi itu terjadi. Menurut Hafid dalam Hikmawati (2012) Mengamati merupakan keterampilan mengumpulkan data atau informasi melalui indera menyimak, mengukur, membaca, mengecap, melihat, mendengar, merasa dengan kulit, dan meraba. Sejalan dengan Gagne dalam Rehalat (2014) mengatakan bahwa tentang pomrosesan informasi yaitu (1) panca indera yang diterima kemudian disalurkan pada syaraf dan diproses sebagai informasi, (2) informasi yang didapat dipilih secara seksama secara selektif dan disimpan dalam memori jangka pendek dan jangka panjang, dan (3) informasi yang sudah didapatkan semuanya kemudian diungkap kembali.Mahasiswa juga dalam kelompok menggunakan bantuan smartphone yang didukung dengan aplikasi zoom cloud meeting untuk berkomunikasi dengan dosen apabila mengalami kendala pada lokasi pengamatan. Kegiatan selanjutnya, mahasiswa dalam kelompok menentukan suatu permasalahan yang terjadi akibat urbanisasi mulai dari judul yang diambil sampai pada bagian referensi yang akan menjadi topik diskusi dalam kelompok. Pada tahapan ini mahasiswa dilatih dan dibelajarkan untuk bagaimana menemukan permasalahan geografi yang ditimbulkan akibat adanya urbanisasi. Tahapan ini juga melatih dan membelajarkan mahasiswa dalam penggunaan smarthphone, sehingga mahasiswa mampu memahami dan mengetahui cara penggunaannya sesuai dengan perkembangan zaman. Kemampuan menggunakan smarthphone merupakan keterampilan dalam proses pembelajaran di abad 21. Sesuai dengan pendapat Handoyo (2012) menggunakan komputer sebagai alat bantu pembelajaran dan menggunakan berbagai media dalam berkomunikasi.

Kedua, mengklasifikasi. Berbagai permasalahan geografi pada bidang pendidikan yang diakibatkan dari adanya urbanisasi yang ditemukan mahasiswa dilapangan kemudian diklasifikasikan. Menurut Hafid dalam Hikmawati (2012) Mengklasifikasikan merupakan keterampilan mengklasifikasikan kenyataan, konsep, nilai, benda, keterampilan, atau tujuan tertentu perbedaan tersebut menjadi dasar untuk mengontraskan, dan membandingkan. Tahapan mengklasifikasi ini merupakan tahapan mencari dan mengetahui secara mendalam permasalahan urbanisasi yang terjadi di kota Malang khususnya pada bidang pendidikan (SD, SMP, SMA). Untuk mengklasifikasi materi pembelajaran yang berbasis konteks dunia nyata harus dipelajari mahasiswa dari permasalahan geografi di abad 21 (Handoyo, 2017). Hal ini agar dari tahapan mengklasifikasi, mahasiswa diharapkan mampu mengklasifikasi masalah secara nyata. Pengklasifikasian yang dianggap penting dalam kelompok dipilih sebagai permasalahan yang menjadi topik diskusi pada setiap kelompok. Menurut Juliandi (2013) permasalahan utama dalam penelitian penting untuk ditetapkan sebagai isu utama dan juga mempunya opsi untuk pemilihan judul. Topik yang dipilih masing-masing kelompok, antara lain (1) urbanisasi di kota Malang, (2) pengaruh tingkat urbanisasi terhadap tingkat urbanisasi bidang pendidikan di kota Malang, (3) pendidikan sebagai salah satu faktor negatif urbanisasi, (4) upaya mengatasi kemacetan di kawasan pendidikan, (5) kepadatan penduduk sebagai dampak urbanisasi dalam bidang pendidikan di kota Malang, dan (6) urbanisasi di kota Malang dari masalah menjadi peluang. Sesuai dengan indikator 
kemampuan menulis karya ilmiah yang kedua yaitu, pada bagian judul. Tahapan yang kedua pada pembelajaran mengunakan model outdoor study berbantuan video conference yang dijabarkan diatas menunujukkan bahwa mahasiswa dilatih untuk melakukan klasifikasi untuk menemukan judul yang tepat sesuai permasalahan urbanisasi. Hal ini didukung dengan fakta bahwa kemampuan menulis karya ilmiah pada indikator bagian judul kelas kelompok eksperimen memperoleh nilai rata-rata gain score sebesar 7,44 unggul jika dibandingkan dengan kelas kelompok kontrol sebesar 5,44. Peningkatan kemampuan membuat judul pada kelas eksperimen merupakan konsekuensi dari pembelajaran yang telah dijalankan.

Ketiga, mengomunikasikan. Pada tahapan komunikasi mahasiswa mengkonfirmasi sudah sejauh mana data yang telah didapatkan kemudian disampaikan dengan dosen maupun dengan teman sekelompok mengenai pengamatan dan pengklasifikasian yang sudah ditemukan dilapangan melalui video conference. Menurut Hafid dalam Hikmawati (2012) komunikasi merupakan menyampaikan tindakan, penampilan, gerak, gambar, kepada orang lain dalam bentuk tulisan, maupun secara lisan. Sejalan dengan pendapat (Handoyo, 2012) dosen atau guru geografi diberikan peran sebagai perantara, fasilitator atau konsultan. Pada tahapan mengkomunikasikan mahasiswa dengan dosen maupun dengan teman kelompok mengungkapkan data yang sudah didapatkan dituliskan sementara dalam LKM (lembar Kerja Mahasiswa) yang telah dibagikan dan yang sudah dirancang kemudian dilengkapi bersama masing-masing kelompok untuk dipresentasikan di depan kelas. Pada tahapan pembelajaran ini, indikator kemampuan menulis karya ilmiah pada bagian pendahuluan memberikan fakta bahwa nilai rata-rata gain score kemampuan menulis karya ilmiah mahasiswa kelas kelompok eksperimen sebesar 6,11 unggul dari kelas kelompokkontrol yaitu sebesar 5,77. Peningkatan kemampuan menulis karya ilmiah bagian pendahuluan kelas eksperimen merupakan konsekuensi dari pembelajaran yang telah dijalankan.

Keempat, mengukur. Pada tahapan mengukur mahasiswa dalam kelompok mengukur, berasumsi/berpersepsi berdasarkan data yang sudah diperoleh pada tahapan sebelumnya. Menurut Hafid dalam Hikmawati (2012) Mengukur merupakan keterampilan menginterpretasikan peristiwa, konsep kenyataan, benda, atau informasi yang telah diperoleh atau dikumpulkan melalui pengamatan, pengukuran, perhitungan, eksperimen atau penelitian sederhana. Mahasiswa melakukan pengukuran terhadap objek/subjek diantara permasalahan akibat urbanisasi khususnya pada bidang pendidikan jenjang SD, SMP, dan SMA di kota Malang. Pada tahap ini mahasiswa menggolongkan, memilah dengan seksama ketiga jenjang pendidikan tersebut mana yang lebih dominan berurbanisasi dan metode penelitian seperti apa yang sesuai dan yang digunakan dalam penelitian setiap kelompok. Hasil pengukuran dari setiap kelompok dicatat dalam lembar kerja mahasiswa. Sejalan dengan pendapat Handoyo (2012) pembelajaran abad 21 dalam bidang pendidikan mahasiswa sehendaknya merancang desain dan meneliti secara mendalam. Fakta yang didapatkan bahwa kemampuan menulis karya ilmiah pada indikator bagian metode kelas eksperimen memperoleh nilai rata-rata gain score sebesar 4,12 lebih kecil dari kelas kontrol 5,09 hal ini karena yang pertama, pada pemilihan metode kelas eksperimen masih dikatakan cukup dalam mendesain elemen-elemenen secara mendalam sesuai kriteria yang ditentukan dan alasan yang kedua karena, kelas kontrol lebih banyak memperoleh data sekunder seperti internet, dan buku, sedangkan kelas eksperimen memperoleh data primer secara langsung. Selisih nilai gain score kedua kelas tidak jauh berbeda dengan memperoleh nilai sebesar 0,97 sehingga tidak menutup kemungkinan kelas eksperimen juga secara tidak langsung merujuk dari internet, buku, dan penjelasan dosen.

Kelima, memprediksi. Pada tahap ini setelah mahasiswa melakukan kegiatan pengukuran selanjutnya setiap kelompok mahasiswa berasumsi/berpersepsi pada objek/subjek yang diamati mengenai urbanisasi pada bidang pendidikan SD, SMP, dan SMA yang ada di kota Malang apa yang akan terjadi ditahun yang akan datang dan bagaimana upaya yang harus dilakukan pemerintah dalam mengatasi permasalahan urbanisasi pada bidang pendidikan tersebut. Menurut Hafid dalam Hikmawati (2012) Memprediksi merupakan sesuatu hal yang akan terjadi pada waktu yang akan datang untuk mengantisipasi atau menyimpulkan kecenderungan hubungan antar data atau informasi berdasarkan pemikiran. Hasil pengukuran disampaikan saat mempresentasikan hasil yang ditemui di lapangan melalui presentasi masing-masing kelompok di depan kelas. Fakta bahwa kemampuan menulis karya ilmiah pada indikator bagian hasil dan pembahasan pada kelas eksperimen memperoleh nilai ratarata gain score sebesar 13, 25 unggul dibandingkan kelas kontrol sebesar 10,87. Peningkatan kemampuan menulis hasil dan pembahasan pada kelas eksperimen merupakan konsekuensi positif dari pembelajaran yang telah dijalankan.

Keenam, menyimpulkan. Pada tahapan ini mahasiswa menarik kesimpulan berdasarkan hasil mengukur dan memprediksi sebelumnya kemudian dicatat dalam lembar kerja mahasiswa. Pada langkah ini juga melalui video conference mahasiswa diminta kembali ke kelas dan menyimpulkan apa yang sudah didapatkan di lapangan. Kemudian, Proses ini akan menghasilkan kesimpulan yang akan menjadi bahan evaluasi dan pengambilan keputusan berkaitan dengan solusi atas permasalahan yang menjadi topik dalam kelompok yang sudah diperoleh di lapangan. Selain itu, penarikan kesimpulan berdasarkan hasil yang sudah didapatkan di lapangan pada masing-masing kelompok sebagai upaya dalam menentukan kemungkinan-kemungkinan yang dapat dilakukan dalam memberikan solusi dan penanggulangannya. Fakta bahwa kemampuan menulis karya ilmiah pada indikator simpulan pada kelas eksperimen memperoleh nilai rata-rata gain score sebesar 8,16 unggul jika dibandingkan dengan kelas kontrol sebesar 8,15. Peningkatan kemampuan memberikan simpulan pada kelas eksperimen dan kelas kontrol merupakan konsekuensi positif dari pembelajaran yang telah dijalankan.

Ketujuh, menulis hasil laporan. Semua informasi yang telah dikumpulkan dan yang sudah diperoleh yakni data primer maupun data sekunder, setiap kelompok pada tahapan sebelumnya dibuat dalam bentuk artikel sebagai laporan akhir setiap kelompok. Pada tahapan ini mahasiswa dalam membuat artikel dibimbing oleh dosen pada jam pelajaran maupun di luar jam pelajaran. Kegiatan ini memberikan gagasan, ide sesuai kesepakatan dalam diskusi kelompok sebagai alternatif dan evaluasi 
berdasarkan fakta yang ada pada lokasi pengamatan pada dua titik lokasi yang berbeda. Kegiatan mengomunikasikan hasil diskusi kelompok memberikan gambaran bahwa kemampuan menulis karya ilmiah pada indikator bagian hasil laporan dituangkan, dilatih, dan dibelajarkan dari rangkaian kegiatan diskusi kelompok.

Kedelapan, mempresentasikan. Tahapan ini merupakan tahapan yang terakhir dari pembelajaran menggunakan model outdoor study berbantuan video conference. Pada tahap ini mahasiswa melakukan presentasi kelompok atas pembelajaran yangtelah dijalankan mulai dari tahapan yang pertama hinggga tahapan yang terakhir. Pada tahapan ini mahasiswa memberi pertanyaan, menanggapi, memberikan solusi dan alternatif yang dapat diambil terkait dengan hasil presentasi setiap kelompok. Kemudian dari hasil presentasi setiap kelompok digunakan sebagai revisi artikel yang akan digunakan atau sebagai bahan pembelajaran di masa yang akan datang.

Kelas kontrol yang menggunakan pembelajaran konvensional mengalami peningkatan namun tidak terlalu besar. model pembelajaran konvensional bentuk ceramah (data, penjelasan konsep, tanya jawab, diskusi). Peningkatan khususnya pada bagian yang terkait dengan data sekunder dan kutipan, seperti metode, dan pembahasan. Alasan kemampuan menulis karya ilmiah kelas kontrol yang menggunakan pembelajaran konvensional tidak unggul dari kelas Eksperimen.

Pertama, kelas kontrol tidak langsung mendapatkan data dan fakta secara rill (nyata) di lapangan melainkan hanya menelaah artikel hasil telaah. Sesuai dengan indikator kemampuan menulis karya ilmiah pada bagian hasil kelas kontrol hanya memperoleh nilai sebesar 10,87 dibandingkan dengan kelas eksperimen yang memperoleh nilai 13,25.

Kedua, ceramah atau penyampaian konsep dan materi yang diberikan oleh dosen kurang diserap dan disimpan secara panjang dalam memori mereka dalam menemukan konsep dan mengorganisasi data. Menurut Gagne dalam Rehalat (2014) mengenai teori template dimana pola/ingatan akan cepat hilang. Sejalan dengan pendapat Atkinson dan shiffrin dalam Rehalat (2014) memori jangka pendek informasi akan hilang dalam waktu 20-30 detik jika tidak diulang hal ini bersifat terbatas baik dalam kapasitas maupun durasi.

Ketiga, mahasiswa pada kelas kontrol selain mengerjakan karya ilmiah yang diberikan oleh dosen, mahasiswa kelompok kelas kontrol saat itu juga memiliki tugas perkuliahan yang sangat banyak sehingga, dalam pembagian konsentrasi mengerjakan karya ilmiah tidak optimal dan juga karena semangat dan emosi kelompok kelas kontrol pada saat itu tidak terkendali. Menurut Hazher dan Zacks dalam Rehalat (2014) mengenai ciri pemrosesan yang membutuhkan usaha (membuat karya ilmiah), yaitu (1) gangguan tugas seharusnya tidak saling menggangu dalam pengerjaan suatu usaha dan (2) kondisi emosi yang tinggi atau rendah dapat menurunkan keefektifan pemrosesan dalam hal yang membutuhkan usaha (membuat karya ilmiah). Hal ini menunjukkan secara keseluruhan kemampuan menulis karya ilmiah yang menggunakan model pembelajaran outdoor study berbantuan video conference lebih baik dibandingkan dengan pembelajaran konvensional.

Rangkaian kegiatan pada proses pembelajaran yang dijalankan menggunakan model pembelajaran outdoor study berbantuan video conference menempatkan dosen sebagai fasilitator (perantara) dalam membimbing mahasiswa menjalankan setiap tahapan pada proses pembejaran. Menurut (Handoyo, 2012) pembelajaran Geografi harus berpusat pada mahasiswa (student centered), demokratis, fleksibel, dosen ata guru Ggrafi diberikan peran sebagai fasilitator atau perantara dan konsultan. Hal ini bertujuan untuk meningkatkan aktivitas dan kreativitas mahasiswa secara mandiri dalam berpikir (mind set) untuk menemukan dan memecahkan permasalahan secara nyata di lingkungan sekitar. Menurut Handoyo (2012) materi pembelajaran yang berbasis konteks dunia nyata yang harus dipelajari mahasiswa. Selain itu, dapat memberikan kemudahan kepada mahasiswa agar dapat belajar dengan penuh semangat, gembira, menyenangkan, dan tidak cemas. Implementasi model pembelajaran outdoor study berbantuan video conference menjadikan dosen bukan lagi sebagai pemberi informasi bagi mahasiswa dalam menyelesaikan dan menjawab permasalahan yang ditemukan dalam proses pembelajaran, melainkan mahasiswa yang harus menjadi pusat perhatian dalam pembelajaran abad 21 ini.

Salah satu keunggulan model pembelajaran outdoor study berbantuan video conference yang ditemukan dalam penelitian ini adalah (1) bagi dosen tidak perlu mendampingi kelompok mahasiswa di kedua tempat yang berbeda, melainkan dosen dapat memanfaatkan pembelajaran secara syncronus (online) dengan mahasiswa yaitu berkomunikasi langsung melalui smarthphone dan laptop dengan cara memberikan arahan, instruksi yang baik dan benar (2) mahasiswa merasa tertantang dengan langsung terjun ke lokasi yang akan diteliti sembari mencoba pembelajaran secara syncronus atau pembelajaran secara online yang semakin canggih di era digital 4.0 saat ini. Model pembelajaran outdoor study berbantuan video conference dapat memberi pengaruh yang baik bagi mahasiswa diantaranya yaitu perspektif diri, kepercayaan, kemampuan mengolah teknologi, dan sikap yang lebih baik. Selain itu, dapat meningkatkan komunikasi dan keterampilan sosial. Menurut Cengelci (2013) mengatakan bahwa pengetahuan, keterampilan, dan nilai-nilai untuk menjadikan seseorang aktif disekitar mahasiswa diperlukan dengan cara mengembangkan studi sosial. Model pembelajaran outdoor study berbantuan video conference mendukung untuk mahasiswa berkomunikasi dengan orang lain dari segala lokasi, meningkatkan keaktifan mahasiswa didalam belajar, memberikan kesehatan pertumbuhan fisik mahasiswa karena aktif terlibat dan bebas bergerak. Model pembelajaran outdoor study berbantuan video conference memberikan peluang bagi mahasiswa untuk terlibat langsung dengan keadaan yang nyata dari lokasi yang berbeda-beda, memberi pengalaman yang tidak ditemukan didalam kelas, dan memberikan mahasiswa pengetahuan teknologi di era digitas saat ini. 
Peningkatan kemampuan menulis karya ilmiah mahasiswa menggunakan model pembelajaran outdoor study berbantuan video conference dibandingkan dengan pembelajaran konvensional (diskusi, tanya jawab, diskusi) ada faktor yang dapat memengaruhi kemampuan menulis karya ilmiah mahasiswa, yakni (1) situasi belajar mahasiswa yang menyenangkan mampu menciptakan situasi belajar yang relatif fleksibel. Kebebasan aktivitas fisik belajar di alam terbuka menjadi salah satu alternatif agar keluar dari rutinitas yang mungkin mengekang siswa dari kebebasan mengembangkan rasa ingin tahu (Sibthorp et al, 2015; Widiasworo, 2017). Mahasiswa tidak merasa dikontrol, melainkan mahasiswa diberikan otoritas untuk mengekspresikan imajinasi dan pikiran mereka terhadap materi yang didapatkan berdasarkan pengamatan langsung di lapangan, serta mengaplikasikannya dalam bentuk karya tulis ilmiah, (2) perkembangan teknologi terkini menjadikan mahasiswa lebih kritis dan kreatif dalam materi pembelajaran. Hasil analisis mahasiswa terhadap suatu fenomena yang ditemukan di lapangan sesuai dengan perkembangan teknologi menggunakan video conference yang dilakukan di luar kelas, dan (3) model pembelajaran outdoor study berbantuan video conference dapat memberikan pemikiran secara mendalam yaitu hal pemrosesan informasi yang terekam dalam otak. Sesuai dengan pendapat Rehalat (2014) informasi yang diperoleh dari alat indera akan dipersepsikan oleh bagian-bagian yang berfungsi secara khusus. Hal ini dikarenakan dengan menggunakan model pembelajaran outdoor study berbantuan video conference mahasiswa mampu menangkap informasi-informasi yang diperoleh dari data di lapangan dan mengolahnya menjadi sebuah pemahaman dengan cara mereka sendiri-sendiri atau secara kelompok menjadi lebih baik. Sesuai dengan pendapat Pinel \& Gross dalam Utomo (2016) konversi pengalaman dan perolehan pengetahuan berhubungan dengan belajar.

\section{SIMPULAN}

Berdasarkan rumusan masalah dari hasil penelitian ini, maka dapat disimpulkan bahwa model pembelajaran outdoor study berbantuan video conference berpengaruh signifikan terhadap kemampuan menulis karya ilmiah mahasiswa. Hasil dari uji two way anova menunjukkan bahwa model pembelajaran outdoor study berbantuan video conference pada kelas eksperimen berpengaruh terhadap kemampuan menulis karya ilmiah dengan nilai signifikan sebesar 0,035 lebih kecil dari 0,05. Hal tersebut membuktikan bahwa rata-rata kemampuan menulis karya ilmiah menggunakan model outdoor study berbantuan video conference mahasiswa kelas eksperimen memperoleh nilai rata-rata gain score sebesar 8,140 lebih tinggi dari kelas kontrol yang memperoleh nilai sebesar 6,961 yang menggunakan pembelajaran konvensional.

Berdasarkan kesimpulan dari penelitian ini, maka dapat disarankan sebagai berikut. Pertama, dosen matakuliah Geografi dapat menggunakan model pembelajaran outdoor study berbantuan video conference untuk meningkatkan kemampuan menulis karya ilmiah karena terbukti dari hasil penelitian ini memberikan hasil yang baik. Kedua, penelitian ini dapat dijadikan landasan bagi peneliti selanjutnya agar menggunkan model pembelajaran outdoor study berbantuan video conference dengan mencoba menggunakan variabel terikat yang berbeda. Selain itu, dapat menggunakan model pembelajaran outdoor study berbantuan video conference terhadap lokasi, jenjang pendidikan, dan materi perkuliahan lainnya.

\section{DAFTAR RUJUKAN}

Ardley, J. (2009). Unanticipated Findings: Gains by Cooperating Teachers via Video- Mediated Conferencing. Journal of Computing in Teacher Education, 25(3), 81-87.

Azwar, H., \& Susantok, M. (2013). Implementasi Video Conference pada Program Pendidikan Jarak Jauh PCRTOL Berbasis Web. Jurnal Teknik Elektro dan Komputer, 1(2), 107-114.

Çengelci, T. (2013). Social Studies Teachers' Views on Learning Outside the Classroom. Kuram ve Uygulamada Egitim Bilimleri, 13(3), 1836-1841. https://doi.org/10.12738/estp.2013.3.1410

Clabough, E. B. D., \& Clabough, S. W. (2016). Using Rubrics as a Scientific Writing Instructional Method in Early Stage Undergraduate Neuroscience Study. Journal of Undergraduate Neuroscience Education: June: A Publication of FUN, Faculty for Undergraduate Neuroscience, 15(1), A85-A93.

Fatchan, A., Soekamto, H., Sumarmi., \& Utaya, S. (2016). Effect of Learning “Outdoor Study” Ability to Communicate in Writing and Social-Geography Student Learning Outcomes at "Mataraman" East Java-The Republic of Indonesia. Mediterranean Journal of Social Sciences, 7(3), 429-435. https://doi.org/10.5901/mjss.2016.v7n3p429

Utomo, D. H. (2017). Brain Based Learning: Effects Model A-Car in Critical Thinking Skills. 79(Icge 2016), 339-343. https://doi.org/10.2991/icge-16.2017.65

Koenig, R. J. (2010). A Study in Analyzing Effectiveness of Undergraduate Course Delivery: Classroom, Online and Video Conference. Contemporary Issues in Education Research, 3(10), 13-26.

Maulidiyahwarti, G., Sumarmi, S., \& Amirudin, A. (2016). Pengaruh Model Problem Based Learning Berbasis Outdoor Study terhadap Hasil Belajar Siswa Kelas XI IIS SMA. Jurnal Pendidikan: Teori, Penelitian, dan Pengembangan, 1(2), 94100.

Purwanto, E., Fatchan, A., \& Soekamto, H. (2015). Development of Geography Text Books Used by Senior High School Teachers Case Study at East Java-Indonesia. Journal of Education and Learning, 5(1), 60. https://doi.org/10.5539/jel.v5n1p60

Rehalat, A. (2016). Model Pembelajaran Pemrosesan Informasi. Jurnal Pendidikan Ilmu Sosial, $23(2), 1$. https://doi.org/10.17509/jpis.v23i2.1625 
Sibthorp, J., Collins, R., Rathunde, K., Paisley, K., Schumann, S., Pohja, M., \& Baynes, S. (2015). Fostering Experiential SelfRegulation Through Outdoor Adventure Education. Journal of Experiential Education, 38(1), $26-40$. https://doi.org/10.1177/1053825913516735

Slavin, R. E. (2000). Educational Psychology, Theory and Practice. United state of America: Allyn \& Bacon.

Sofnidar., Khamid., \& Anwar, K. (2017). Desain Sintak Model Outdoor Learning Berbasis Modelling Mathematics. EDUMATICA: Jurnal Pendidikan Matematika, 7(02), 1-10. https://doi.org/10.22437/edumatica.v7i02.4211

Sudarman., Handoyo, B., \& Utomo, D. H. (2018). Meningkatkan Hasil Belajar Geografi menggunakan Model Pembelajaran Inkuiri Terbimbing Berbantuan Media Visual. Jurnal Pendidikan: Teori, Penelitian, dan Pengembangan, 3(3), $377-381$.

Sumarmi. (2012). Model-Model Pembelajaran Geografi.Yogyakarta: Aditya Media Publishing.

Susetyo, B. B., Sumarmi., \& Astina, I. K. (2017). Pengaruh Pembelajaran Problem Based Learning Berbasis Outdoor Adventure Education terhadap Kecerdasan Spasial. Jurnal Pendidikan: Teori, Penelitian, dan Pengembangan, 2(12), 1669-1675.

Szczepanski, A., Malmer, K., Nelson, N., \& Dahlgren, L. O. (2006, June). Outdoor Education-Authentic Learning in the Context of Landscape Literary Education and Sensory Experience. Perspective of Where, What, Why, How and When of learning environments. Inter-Disciplinary Context and the Outdoor and Indoor Dilemma. In The Third International Outdoor Education Research Conference-Widening Horizons: Diversity in Theoretical and Critical Views of Outdoor Education Conference. Retrieved from https://old.liu.se/ikk/ncu/ncu_filarkiv/Forskning/1.165263/AndersSzczepanski.pdf Vera, A. (2012). Metode Mengajar Anak di Luar Kelas (outdoor study). Yogyakarta: DIVA Press.

Widiasworo, E. (2017). Strategi dan Metode Mengajar Siswa di Luar Kelas (outdoor learning) Secara Aktif, Kreatif, Inspiratif, \& Komunikatif. Yogyakarta: AR-RUZZ Media. 